\title{
Extent of the High Water Table and Water-Table Fluctuations, St. Charles Mesa, Colorado, April 1997 to October 1998
}

\section{Introduction}

St. Charles Mesa (Mesa) is an upland terrace southeast of Pueblo with an area of about 10 square miles (fig. 1). The Mesa has been irrigated for agricultural purposes since the late 1800's (Dumeyer, 1975). The unconfined sand and gravel aquifer, originally deposited by the Arkansas River, overlies an eroded shalebedrock surface (Scott, 1969). During the last several decades, the Mesa has become increasingly urbanized as cultivated fields have been converted to residential areas. Because the water table is near the land surface in parts of the Mesa, basement flooding has occurred. In addition, the high water table has caused concern that flooding of domestic septic systems could cause degradation of ground-water quality. To better define the hydrology of the area, the U.S. Geological Survey (USGS), in cooperation with Pueblo County, began a study in 1997. This report describes the extent of the high water table and water-table fluctuations from April 1997

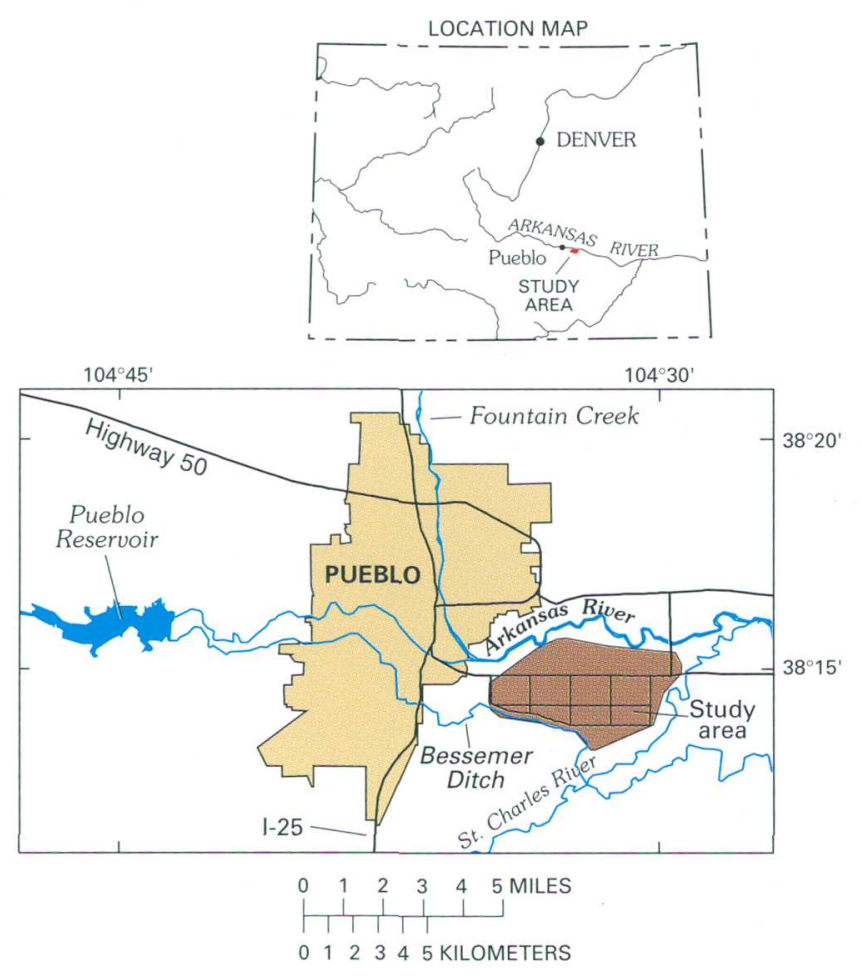

Figure 1. Location of study area. to October 1998. The measurement of the water table used in this study is the depth to the water table below land surface, called depth to water. The depth to water was measured in 57 wells weekly, biweekly, or monthly. The frequency of measurements depended on whether the well was in an area where (1) basement flooding has occurred, or (2) seasonal changes in the depth to water were expected to occur rapidly.

\section{Water-table fluctuations}

The depth to water on the Mesa fluctuates because of (1) recharge from precipitation, (2) recharge of irrigation water conveyed seasonally through the Bessemer Ditch (fig. 1) and its laterals, (3) infiltration of water from lawn and crop irrigation and septic-system effluent, (4) discharge of water by evaporation or transpiration, (5) discharge of water by well pumpage, and (6) discharge of ground water through springs on the northern and eastern edges of the Mesa. The depth to water is controlled by the balance between the amount of water that recharges the aquifer and the amount of water that discharges from the aquifer. If more water recharges the aquifer than discharges, the depth to water will decrease, and if more water is discharged than is being recharged, the depth to water will increase.

Long-term fluctuations in the depth to water in wells can occur over several years or decades. For example, the depth to water in well SC02106403DAC was substantially shallower in wet years (fig. 2A) than it was in dry years (fig. 2B). Depth-towater measurements in this well were discontinued after 1983. The depth to water fluctuated annually an average of about 2 feet from 1934 to 1982; the maximum change within a year was 6.3 feet between November 1964 and April 1965, and the difference between the deepest (in 1977) and shallowest (in 1942) depth to water was 13.3 feet.

Seasonally, the deepest depth to water usually occurs in late winter or early spring, and the shallowest depth to water usually occurs in summer or autumn (fig. 3). Annual fluctuations between the deepest and shallowest depths to water for wells measured for this study ranged from more than 15 feet to less than 1 foot (table 1). Depending on the location of a well on the Mesa, the seasonal fluctuation in the depth to water in a well can be large (13.76 feet in well 44) or small (2.50 feet in well 24) (fig. 3; table 1). All wells in which the depth to water fluctuated 6 feet or more between April 1997 and October 1998 were near the southern edge of the Mesa (fig. 4). 
Table 1. Map numbers, local identification number, calculated depth to water in wells in November 1997, maximum and minimum depths to water during May 1997 to October 1998, and the difference between the maximum and minimum depths to water

\begin{tabular}{|c|c|c|c|c|c|}
\hline $\begin{array}{c}\text { Map } \\
\text { number } \\
\text { (figs. 4 } \\
\text { and 6) }\end{array}$ & $\begin{array}{l}\text { Local } \\
\text { identification } \\
\text { number }\end{array}$ & $\begin{array}{c}\text { Calculated } \\
\text { depth to } \\
\text { water } \\
\text { (feet); } \\
\text { November } \\
1997\end{array}$ & $\begin{array}{l}\text { Maximum } \\
\text { depth to } \\
\text { water } \\
\text { (feet) }\end{array}$ & $\begin{array}{l}\text { Minimum } \\
\text { depth to } \\
\text { water } \\
\text { (feet) }\end{array}$ & $\begin{array}{c}\text { Difference } \\
\text { between } \\
\text { maximum } \\
\text { and } \\
\text { minimum } \\
\text { depths to } \\
\text { water } \\
\text { (feet) }\end{array}$ \\
\hline 1 & SC02106414BCCB1 & 28.34 & 33.44 & 21.75 & 11.69 \\
\hline 2 & SC02106410DDCD1 & 23.74 & 31.40 & 15.46 & 15.94 \\
\hline 3 & SC02106411CBAB1 & 17.74 & 22.53 & 16.02 & 6.51 \\
\hline 4 & SC02106414ABBC1 & 24.02 & 30.21 & 21.40 & 8.81 \\
\hline 5 & SC02106414AAAB1 & 21.81 & 29.20 & 21.27 & 8.93 \\
\hline 6 & SC02106412CDAA1 & 22.69 & 24.83 & 20.59 & 4.24 \\
\hline 7 & SC02106412ACBC1 & 25.12 & 28.73 & 25.19 & 3.54 \\
\hline 8 & SC02106411AACD1 & 21.44 & 25.36 & 20.28 & 5.08 \\
\hline 9 & SC02106401DACA1 & 24.20 & 26.91 & 24.25 & 2.66 \\
\hline 10 & SC02106306BCD1 & 21.29 & 21.51 & 19.89 & 1.62 \\
\hline 11 & SC02106401A1 & 16.35 & 17.34 & 16.23 & 1.11 \\
\hline 12 & SC02106401ACCB1 & 16.17 & 17.81 & 15.44 & 2.37 \\
\hline 13 & SC02106401BBCC1 & 10.52 & 11.87 & 10.58 & 1.29 \\
\hline 14 & SC02106401BCCC1 & 9.98 & 12.52 & 10.08 & 2.44 \\
\hline 15 & SC02106402DBDC1 & 9.40 & 12.56 & 9.53 & 3.03 \\
\hline 16 & SC02106402DBCB1 & 11.52 & 13.04 & 10.52 & 2.52 \\
\hline 17 & SC02106402BADC1 & 11.26 & 11.38 & 8.58 & 2.80 \\
\hline 18 & SC02106402CBBB1 & 15.46 & 17.22 & 14.05 & 3.17 \\
\hline 19 & SC02106402BCCC1 & 17.11 & 19.30 & 15.95 & 3.35 \\
\hline 20 & SC02106402CACC1 & 11.47 & 14.13 & 10.65 & 3.48 \\
\hline 21 & SC02106402CDCDC1 & 5.48 & 9.23 & 5.02 & 4.21 \\
\hline 22 & SC02106402CCDC1 & 3.56 & 5.42 & 2.42 & 3.00 \\
\hline 23 & SC02106411BCBB1 & 13.16 & 15.79 & 11.55 & 4.24 \\
\hline 24 & SC02106403DDCC1 & 5.07 & 6.50 & 4.00 & 2.50 \\
\hline 25 & SC02106403DCDB1 & 7.66 & 9.50 & 7.13 & 2.37 \\
\hline 26 & SC02106403DAC2 & 15.37 & 18.66 & 15.01 & 3.65 \\
\hline 27 & SC02106403DBBC1 & 17.21 & 19.40 & 15.68 & 3.72 \\
\hline 28 & SC02106403DBCD1 & 8.55 & 10.99 & 8.85 & 2.14 \\
\hline 29 & SC02106403CBAB1 & 20.85 & 23.47 & 19.18 & 4.29 \\
\hline 30 & SC02106403CDBA1 & 5.30 & 6.87 & 4.75 & 2.12 \\
\hline 31 & SC02106403CDDB1 & 4.93 & 7.52 & 4.17 & 3.35 \\
\hline 32 & SC02106410ACB1 & 12.17 & 15.65 & 12.21 & 3.44 \\
\hline 33 & SC02106410DBCD1 & 19.28 & 26.80 & 16.91 & 9.89 \\
\hline 34 & SC02106410CBCC1 & 15.07 & 21.40 & 11.58 & 9.82 \\
\hline 35 & SC02106410BCCB1 & 5.31 & 5.28 & 4.41 & 0.87 \\
\hline 36 & SC02106410BBCB1 & 8.96 & 10.25 & 8.34 & 1.91 \\
\hline 37 & SC02106402BCCA1 & 5.44 & 9.65 & 4.83 & 4.82 \\
\hline 38 & SC02106404DAAB1 & 7.13 & 7.39 & 5.41 & 1.98 \\
\hline 39 & SC02106404DCBB1 & 16.13 & 17.04 & 12.19 & 4.85 \\
\hline 40 & SC02106409ABDD1 & 16.74 & 19.19 & 14.73 & 4.46 \\
\hline 41 & SC02106409BAAD1 & 17.63 & 20.29 & 14.53 & 5.76 \\
\hline 42 & SC02106409DBAA1 & 10.88 & 15.20 & 10.91 & 4.29 \\
\hline 43 & SC02106409CB1 & 10.85 & 15.10 & 8.90 & 6.20 \\
\hline 44 & SC02106407DACC1 & 20.18 & 26.87 & 13.11 & 13.76 \\
\hline 45 & SC02106408ACC1 & 17.87 & 24.36 & 12.50 & 11.86 \\
\hline 46 & SC02106408AADD1 & 10.22 & 13.65 & 6.72 & 6.93 \\
\hline 47 & SC02106405DCBC1 & 28.38 & 29.78 & 27.62 & 2.16 \\
\hline 48 & SC02106405DAAC1 & 31.04 & 32.11 & 28.70 & 3.41 \\
\hline 49 & SC02106404CACC1 & 23.16 & 23.84 & 19.80 & 4.04 \\
\hline 50 & SC02106404ACCB1 & 22.74 & 23.08 & 20.21 & 2.87 \\
\hline 51 & SC02106404AABD1 & 3.94 & 5.81 & 3.06 & 2.75 \\
\hline 52 & SC02106404AA1 & 13.05 & 13.85 & 11.76 & 2.09 \\
\hline 53 & SC02106403BBBB1 & 4.69 & 6.46 & 4.70 & 1.76 \\
\hline 54 & SC02106403BBCC1 & 10.49 & 12.90 & 9.66 & 3.24 \\
\hline 55 & SC02106403BABC1 & 3.20 & 6.50 & 3.43 & 3.07 \\
\hline 56 & SC02106403ABCC1 & 22.17 & 23.38 & 20.03 & 3.35 \\
\hline 57 & SC02106403AB1 & 3.75 & 4.92 & 3.17 & 1.75 \\
\hline
\end{tabular}

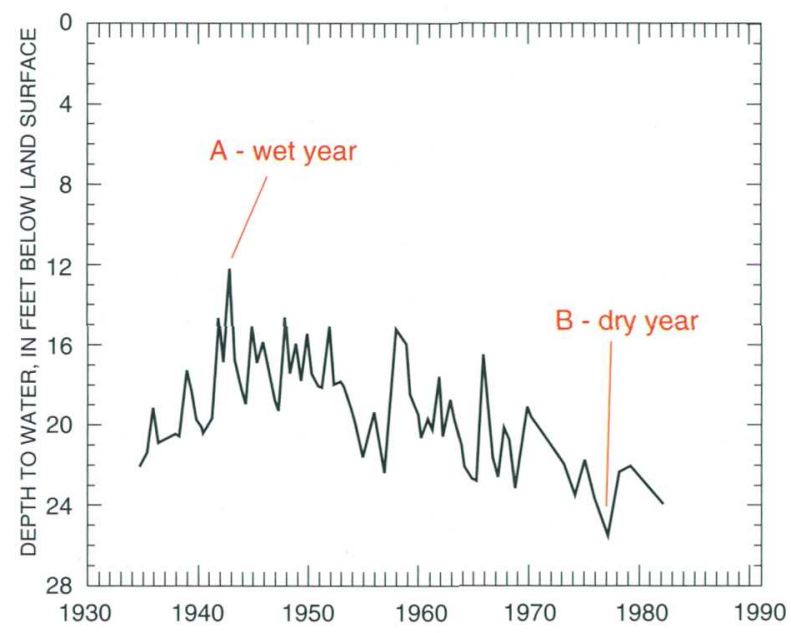

Figure 2. Long-term depth to water in well SC02106403DAC, which was on Santa Fe Drive between 25th and 27th Lanes.

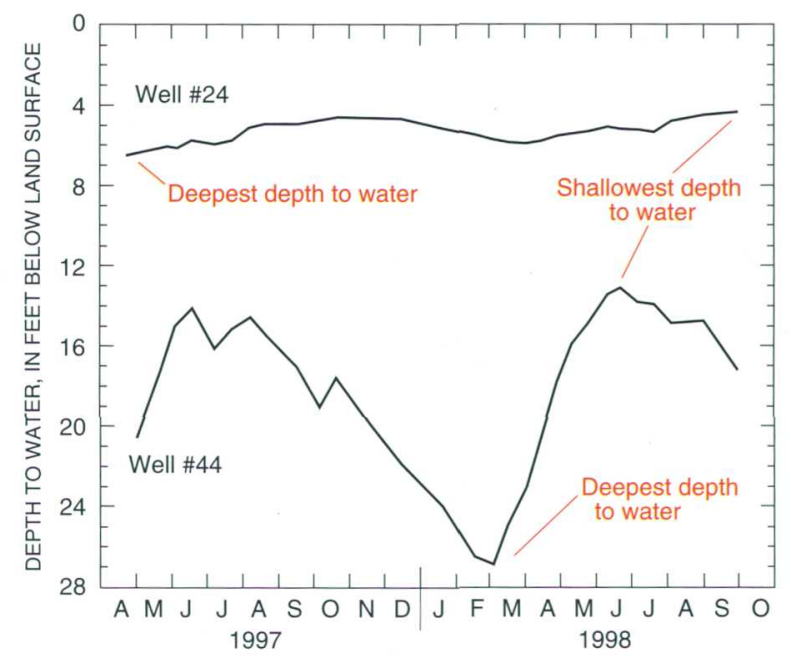

Figure 3. Monthly fluctuations in the depth to water in wells 24 and 44 on St. Charles Mesa (well locations shown in fig. 6).

\section{Why is the high water table a problem for some Mesa residents and not for others?}

Basement flooding can occur in one home while basements in neighboring homes may not become flooded. Several factors determine whether there may be basement flooding in a particular location on the Mesa (fig. 5):

- The depth to water ranges from less than 3 feet to more than 33 feet, depending on the location on the Mesa (table 1).

- The depth of a basement below land surface depends on the design of the house (fig. 5, basements 1 and 2).

- Basement flooding can occur if the bottom of a basement lies at a depth that is between the seasonally deepest and shallowest depths to water (fig. 5, basement 2).

- Pumping of nearby wells can increase the depth to water to a level that is below the bottom of a basement (fig. 5, basements 3 and 4). 


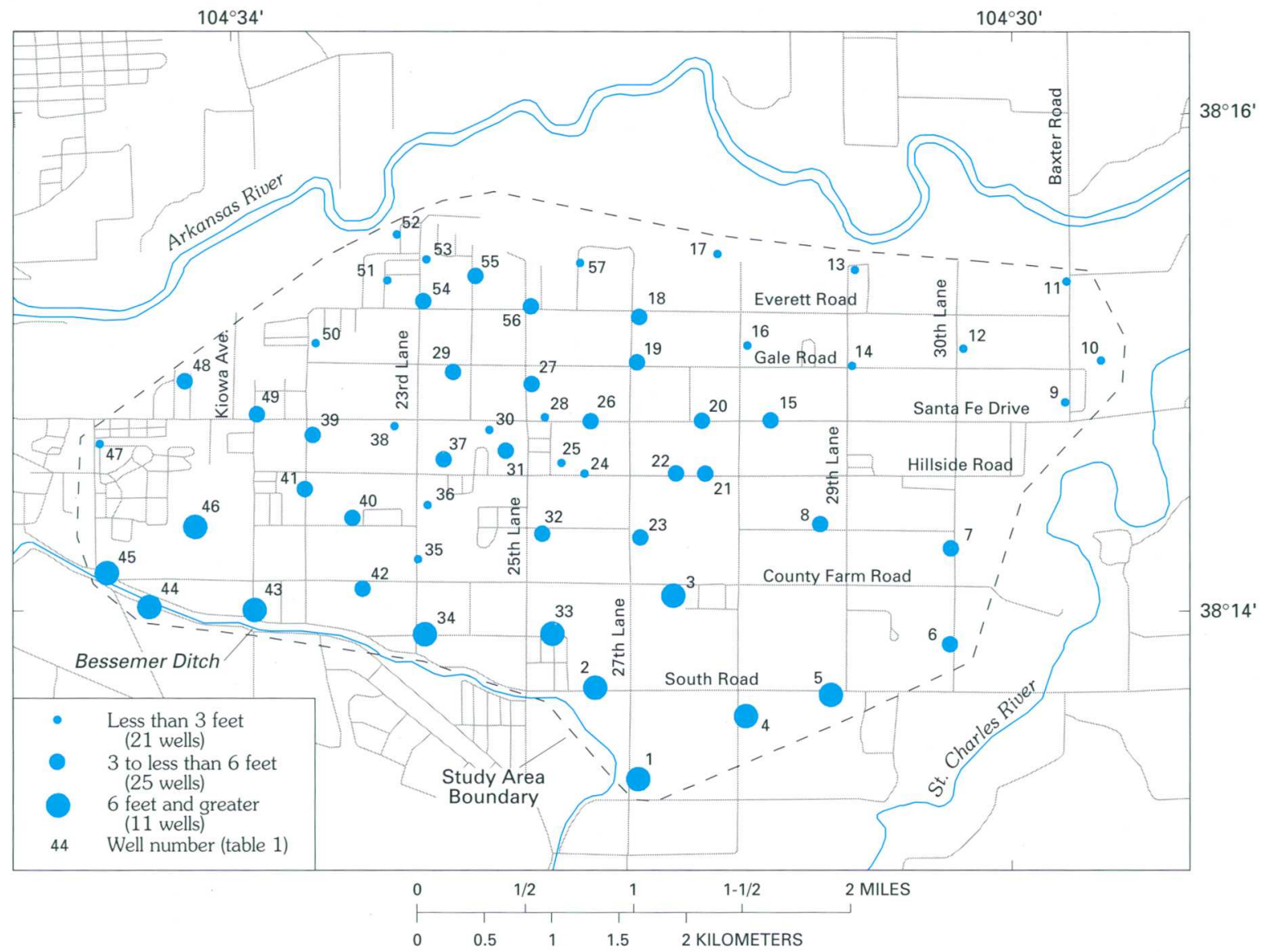

Figure 4. Maximum change in depth to water in wells, St. Charles Mesa (April 1997 to October 1998).
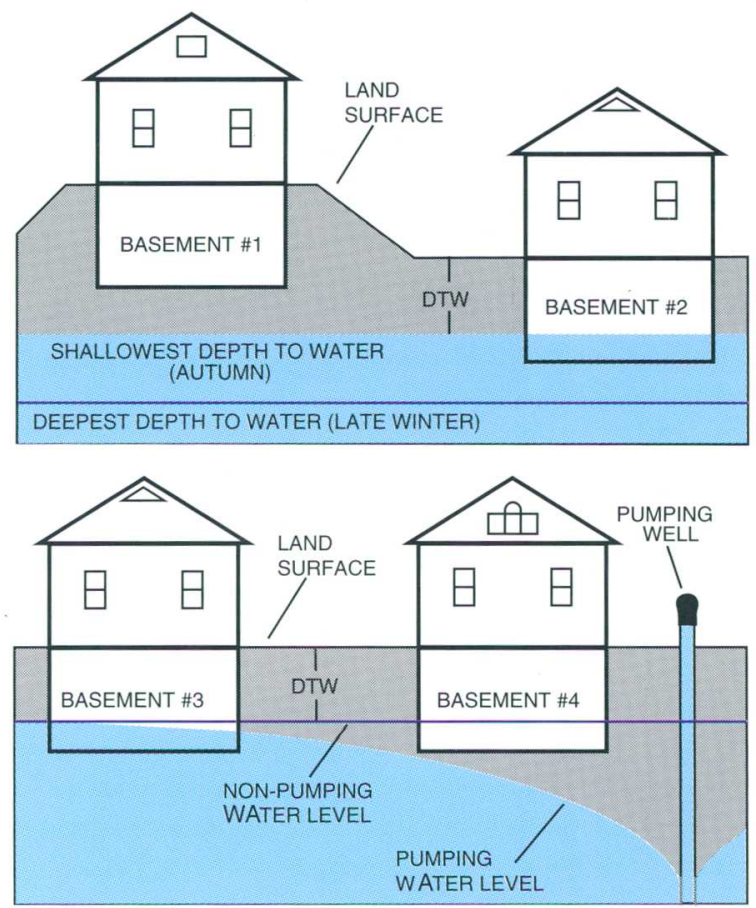

Figure 5. The relation between the depth of a basement and the depth to water (DTW), how that relation determines whether a basement can become flooded, and the effect of a pumping well on the depth to water.

\section{Areas where the high water table may be a problem}

The November 1997 depth-to-water measurements were selected to represent the high water table because the highest water table occurs in most wells in autumn. The November measurements were converted to elevations of the water table above sea level, which were used to create a water-table surface. A land-surface-elevation map was created by digitizing the topographic contours, with a 10-foot interval, from the USGS topographic maps of the area. The water-table surface was subtracted from the land-surface-elevation map to yield a calculated depth to water. The advantages of using this method were (1) the changes in the land-surface elevation could be taken into account, and (2) the depth to water could be calculated where there were no measurements. These calculated depths to water were then contoured to produce the depth-to-water map (fig. 6). The differences between the calculated and measured depths to water in wells ranged from 0.01 to 1.75 feet; the average difference was 0.34 foot in 95 percent of the wells, and the difference was less than 0.5 foot in 40 wells. 


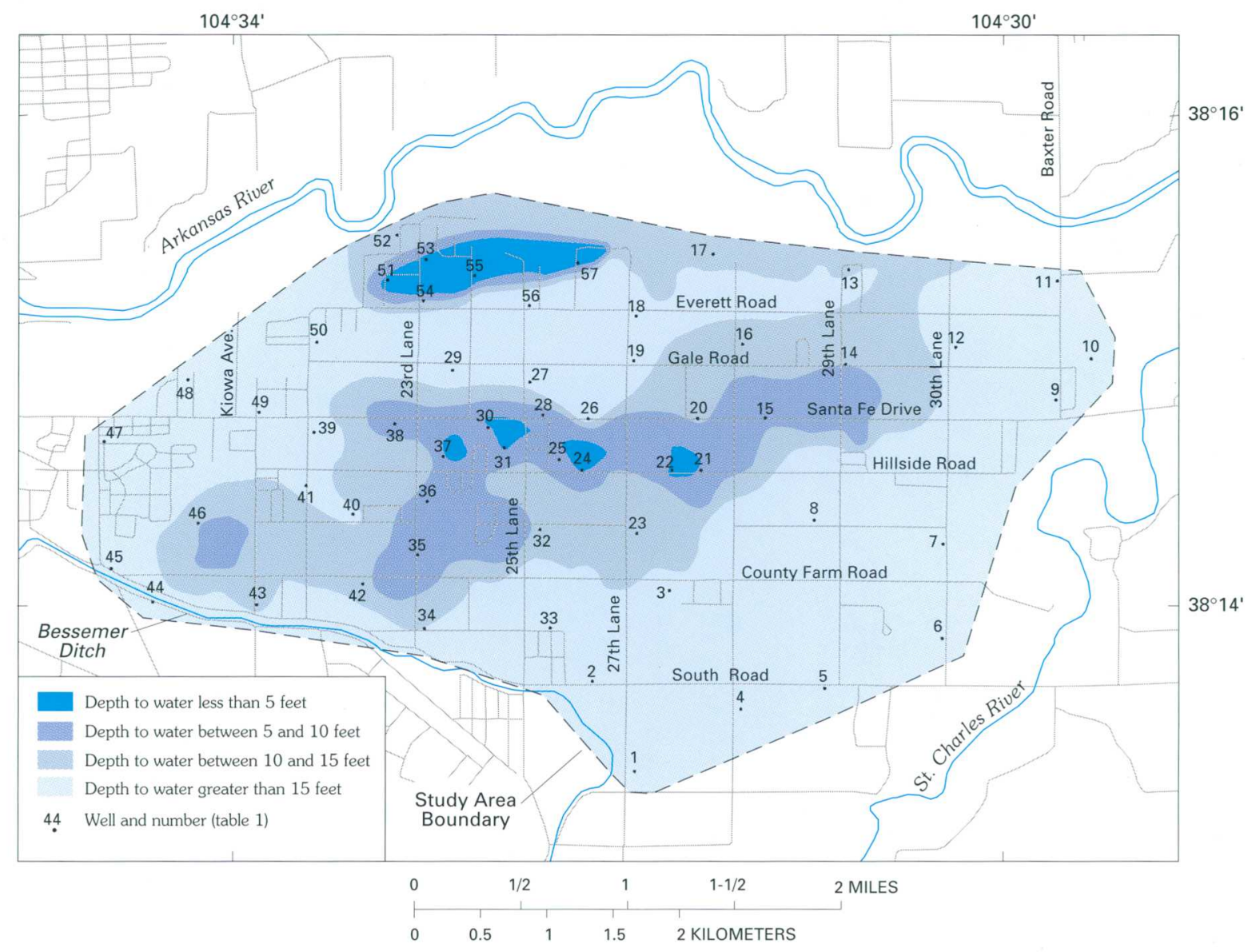

Figure 6. Calculated depth to water, St. Charles Mesa, November 1997.

It was assumed that a 10-foot depth to water would be near the bottom of at least some of the basements on the Mesa. Therefore, where the calculated depths to water were less than 10 feet, basement flooding could occur (fig. 6). In November 1997, a high water table appears to have existed in three areas: (1) On the northern side of the Mesa, generally north of Everett Road and from west of 23rd Lane to about 27th Lane; (2) from Gale Road on the north to just south of County Farm Road and from west of 23rd Lane to east of 29th Lane; and (3) near well 46 north of County Farm Road.

\section{References}

Dumeyer, J.M., 1975, Hydrogeology of St. Charles Mesa, Pueblo County, Colorado: Colorado Geological Survey, Department of Natural Resources, map report, 1 p.

Scott, G.R., 1969, Geologic map of the southwest and southeast Pueblo quadrangles, Colorado: U.S. Geological Survey Miscellaneous Geologic Investigations Map I-597, scale 1:24,000, 1 sheet.

—Daniel L. Brendle, Water Resources Division, Pueblo, Colo.

\section{For more information, please contact:}

\author{
Subdistrict Chief \\ U.S. Geological Survey \\ 201 West 8th Street, Suite 200 \\ Pueblo, CO 81003 \\ (719) 544-7155, ext. 130
}

